\title{
The role of cyclooxygenase-2 on endurance exercise training in female LDL-receptor knockout ovariectomized mice
}

\author{
FLAVIA DE OLIVEIRA ${ }^{1}$, LAURA B.M. MAIFRINO ${ }^{2,3}$, GUSTAVO P.P. DE JESUS ${ }^{1}$, \\ JULIANA G. CARVALHO ${ }^{1}$, CLÁUDIA MARCHON ${ }^{2}$ and DANIEL A. RIBEIRO ${ }^{1}$ \\ ${ }^{1}$ Departamento de Biociências, Universidade Federal de São Paulo, Campus Baixada Santista, \\ Avenida Ana Costa, 95, Vila Mathias, 11060-001 Santos, SP, Brasil \\ ${ }^{2}$ Laboratório de Análises Morfoquantitativa e Imunohistoquímica, \\ Universidade São Judas Tadeu, Rua Taquari, 546, Móoca, 03166-000 São Paulo, SP, Brasil \\ ${ }^{3}$ Instituto Dante Pazzanese de Cardiologia, \\ Av. Dr. Dante Pazzanese, 500, Vila Mariana, 04012-180 São Paulo, SP, Brasil
}

Manuscript received on October 9, 2012; accepted for publication on March 12, 2013

\begin{abstract}
Estrogen deprivation in postmenopausal women increases cardiovascular risk. Cardiovascular risk as a result of atherosclerosis is able to induce an inflammatory disease as far as cyclooxygenase-2 (COX-2) expression. The purpose of the study was to investigate the role of COX-2 on exercise training in female mice low-density lipoprotein receptor knockout (LDL-KO) with or without ovariectomy. A total of 15 female C57BL/6 mice and 15 female LDL-KO mice were distributed into 6 groups: sedentary control, sedentary control ovariectomized, trained control ovariectomized, LDL-KO sedentary, LDL-KO sedentary ovariectomized and LDL-KO trained ovariectomized. The ascending part of the aorta was stained with $\mathrm{H} \& \mathrm{E}$ and COX-2 expression was assessed by immunohistochemistry. Results revealed that ovariectomy as well as exercise training were not able to induce histopathological changes in mouse aorta for all groups investigated. LDL-KO mice demonstrated plaque containing cholesterol clefts, foamy histiocytes and mild inflammatory process for all groups indistinctly. Ovariectomy induced a strong immunoexpression in atherosclerosis lesion of LDL-KO mice. Nevertheless, a down-regulation of COX-2 expression was detected in LDL-KO trained ovariectomized when compared to LDL-KO sedentary. Our results are consistent with the notion that exercise training is able to modulate COX-2 expression in LDL-KO mice as a result of COX-2 down-regulation.
\end{abstract}

Key words: atherosclerosis, Ciclooxygenase-2, exercise, menopause.

\section{INTRODUCTION}

Menopause is a critical period in a woman's life, characterized by decreased ovarian hormone production due to age (Ludgero-Correia et al. 2011). Removal of ovarian hormones in mice

Correspondence to: Flavia de Oliveira

E-mail: flavia.oliveira@unifesp.br by ovariectomy mimics women in menopause, increasing the susceptibility to obesity and its associated comorbidities, as far as inflammation (Hong et al. 2009, Vieira et al. 2007). Atherosclerosis has particular interest, as it may be the underlying cause of myocardial infarction and ischemic stroke as a result of an inflammatory disease (Ross 1999). 
Cyclooxygenase (COX) plays a key role in the conversion of arachidonic acid to prostaglandins in inflammation. COX has 2 isoforms: COX-1, expressed by most tissues and mediates normal physiological functions; and COX-2, rapidly induced at sites of inflammation (Burleigh et al. 2002). According to studies with human atherosclerotic lesions, COX-2 is expressed by endothelial cells, smooth cells and macrophages (Schonbeck et al. 1999, Baker et al. 1999).

Accumulating evidence suggests the benefits of exercise on body weight, bone constitution, muscle strength and endurance, flexibility, oxygen consumption, blood pressure, and metabolic control after menopause (Asikainen et al. 2004). In addition, regular exercise offers protection against mortality, primarily by protection against cardiovascular disease (Petersen and Pedersen 2005). However, it would be interesting to know if, and to what extent, exercise training is able to modulate COX-2 expression in mice suffering atherosclerosis and menopause, particularly because there are no previous reports. Therefore, the purpose of the present study was to investigate if exercise training associated or not with menopause is able to modulate the inflammatory process as a result of COX-2 expression in mice suffering atherosclerosis.

\section{MATERIALS AND METHODS}

\section{ANIMALS AND GROUPS}

All experiments were performed on 15 female C57BL/6 mice and 15 female low-density lipoprotein receptor knockout mice LDL-KO (20$25 \mathrm{~g})$ from the Animal Shelter of Universidade São Judas Tadeu, São Paulo, Brazil. The mice received standard laboratory chow and water ad libitum. The animals were housed in cages in a temperature-controlled room $\left(22^{\circ} \mathrm{C}\right)$ with a 12-h dark-light cycle. All mice were treated similarly in terms of daily manipulation. All surgical procedures and protocols were approved by the Experimental Animal Use Committee of Universidade São Judas Tadeu (058/2007). The mice were randomly assigned to one of six groups ( $n=5$ per group): sedentary control (G1), sedentary control ovariectomized (G2), trained control ovariectomized (G3), LDL-KO sedentary (G4), LDL-KO sedentary ovariectomized (G5) and LDL$\mathrm{KO}$ trained ovariectomized (G6).

\section{OVARIECTOMY}

At nine months of age, animals were anesthetized (Ketamine $120 \mathrm{mg} / \mathrm{Kg}+$ Xylazin $20 \mathrm{mg} / \mathrm{Kg}$ ), and a small abdominal incision was made. The ovaries were then located, and a silk thread was tightly tied around the oviduct, including the ovarian blood vessels. The oviduct was sectioned and the ovary removed. The skin and muscle wall were then sutured with silk thread (Marsh et al. 1999, Irigoyen et al. 2005).

\section{EXERCISE TRAINING}

All animals from trained groups (G3 and G6) were adapted to the treadmill $(10 \mathrm{~min} /$ day; $0.3 \mathrm{Km} / \mathrm{h})$ for 3 days prior to beginning the exercise training protocol. A maximal treadmill test (Irigoyen et al. 2005, Souza et al. 2007, Rodrigues et al. 2007) was performed in trained groups a week after ovariectomy: first at the beginning of the experiment; in a second time in the fourth weeks of the training protocol. The purpose was to determine aerobic capacity and exercise training intensity. Exercise training was performed on a motor treadmill at low-moderate intensity ( $\sim 50$ $60 \%$ maximal running speed) for one hour a day, 5 days a week for 4 weeks, with a gradual increase in speed from 0.3 to $1.2 \mathrm{Km} / \mathrm{h}$.

\section{HistopathOLOGICAL ANALYSIS}

The ascending part of aorta were taken and kept in $10 \%$ formalin buffered for $24 \mathrm{~h}$. The specimens were routinely embedded in paraffin blocks and cut in 
transversal sections $(3 \mu \mathrm{m})$. The slides were stained with hematoxylin and eosin. The specimens were analyzed with light microscope (Axio Observer.D1 Zeiss ${ }^{\circledR}$, Germany).

\section{IMMUNOHISTOCHEMISTRY}

Paraffin was removed with xylene from serial sections of $3 \mu \mathrm{m}$ and the sections were rehydrated in graded ethanol. Then, they were pretreated in a microwave with $0.01 \mathrm{M}$ citric acid buffer $(\mathrm{pH} 6)$ for three cycles of 5 minutes each at $850 \mathrm{~W}$ for antigen retrieval. The material was pre-incubated with $0.3 \%$ hydrogen peroxide in phosphate-buffered saline (PBS) solution for 5 minutes to inactive the endogenous peroxidase and then blocked with 5\% normal goat serum in PBS solution for 10 minutes. The specimens were then incubated with antiCOX-2 polyclonal primary antibody (Santa Cruz Biotechnology, Santa Cruz, CA) at a concentration of 1:200. Incubations were carried out overnight at $4{ }^{\circ} \mathrm{C}$ in a refrigerator. This was followed by two washes in PBS for 10 minutes. The sections were then incubated with biotin-conjugated secondary antibody anti-rabbit IgG (Vector Laboratories, Burlingame, CA) at a concentration of 1:200 in PBS for 1 hour. The sections were washed twice with PBS followed by the application of performed avidin biotin complex conjugated to peroxidase (Vector Laboratories) for 45 minutes. The bound complexes were visualized by the application of a $0.05 \%$ solution of 3-3 - diaminobenzidine solution and counterstained with Harris hematoxylin. On control studies of the antibodies, the serial sections were treated with rabbit IgG (Vector Laboratories) at a concentration of 1:200 in place of the primary antibody. Additionally, internal positive controls were performed with each staining bath.

\section{QUANTIFICATION OF IMMUNOHISTOCHEMISTRY}

Sections stained using immunohistochemistry were analyzed for the percentages of immunopositive cells in control and "hot spot" areas. A total of 1,000 cells were evaluated in 3 to 5 fields at 400X magnification. These values were used as labeling indices.

\section{STATISTICAL METHODS}

Statistical analysis was perfomed by Kruskal-Wallis non-parametric test followed by the Dunn's test using SPSS software pack (version 1.0). "p" value $<0.05$ was considered for statistic significance.

\section{RESULTS}

\section{HistopathologicAL ANALYSIS}

The histopathological evaluation revealed that there were no remarkable changes in the sedentary control group (G1) (Figure 1A) as well as in control mice submitted to ovariectomy (G2) (Figure 1B) and/or trained ovariectomized (G3) (Figure 1C). However, LDL-KO sedentary mice revealed histopathological changes such as the presence of

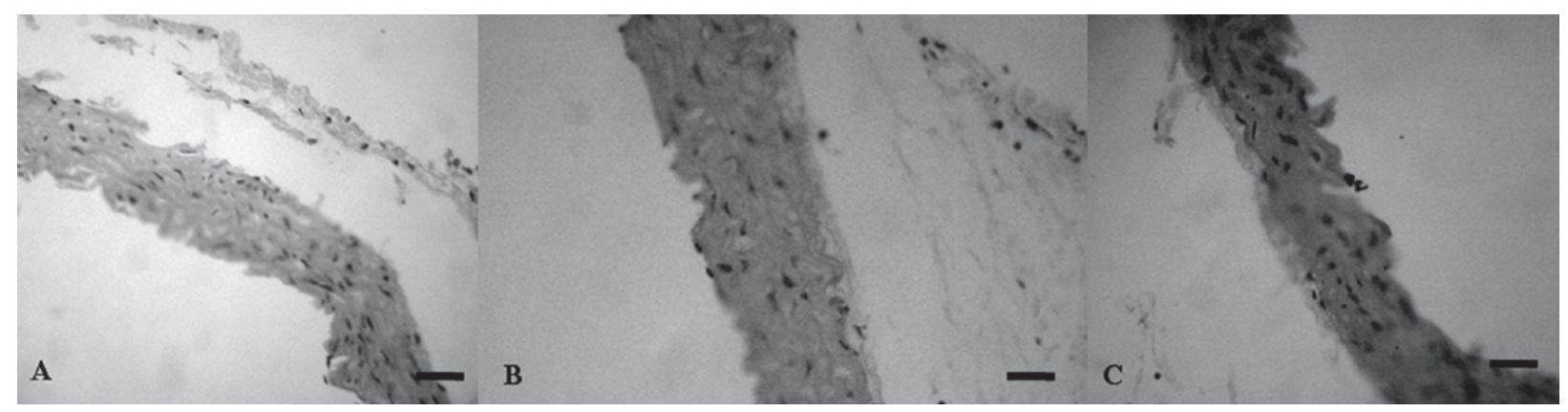

Figure 1 - Histopathological evaluation of groups G1, G2 and G3. In 1A, sedentary control (G1); In 1B, sedentary control and ovariectomized group (G2) and in 1C trained control ovariectomized group (G3). H\&E staining. Scale Bar $=100 \mu \mathrm{m}$. 
plaque with cholesterol clefts, foamy histiocytes, and mild inflammatory process (G4) (Figure 2A). The ovariectomy (G5) or ovariectomy associated with exercise training (G6) did not interfere with the presence of atherosclerosis in LDL-KO mice (Figures 2B and 2C, respectively).

\section{IMMUNOHISTOCHEMICAL DATA}

Immunohistochemical pattern was considered cytoplasmic for COX-2 immunomarker investigated in this setting.

In the sedentary control group (G1), COX2 immunoexpression was weak in the aorta wall (Figure 3A). In the same way, experimental sedentary control ovariectomized (G2) or trained control ovariectomized (G3) was considered negative indistincly for COX-2 immunoexpression (Figures 3B and 3C, respectively).

Regarding LDL-KO sedentary group (G4), a moderate immunoexpression was detected (Figure 4A). However, the association with LDL-KO and ovariectomy (G5) induced a strong pattern of COX-2 immunoexpression in some cells of atherosclerosis lesion (Figure 4B). The LDL$\mathrm{KO}$ ovariectomized and trained (G6) was able to decrease COX-2 expresssion when compared to G4 (Figure 4C). Such findings are summarized in the graph showed in Figure 5.

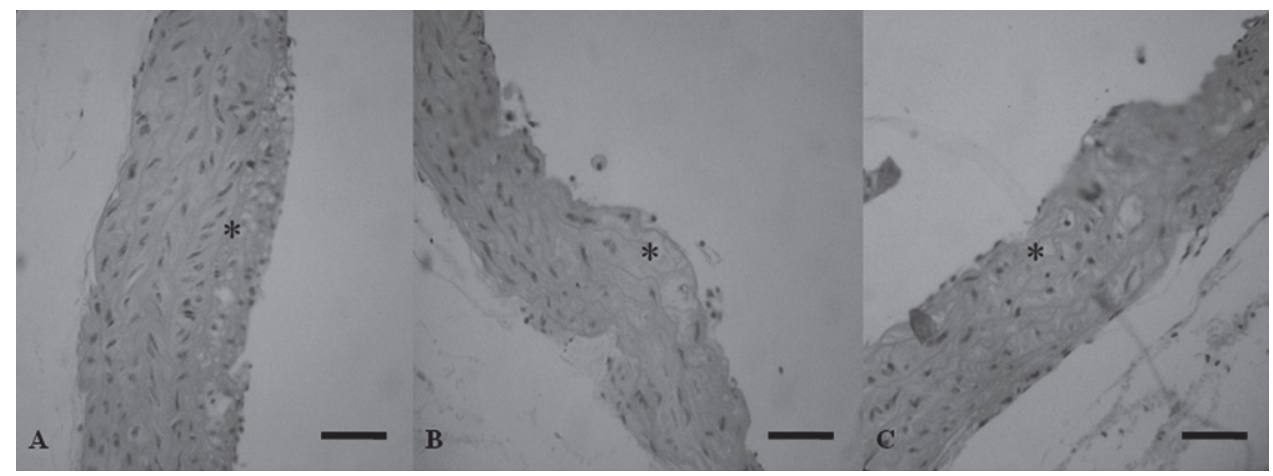

Figure 2 - Histopathological evaluation of groups G4, G5 and G6. In 2A, LDL-KO sedentary group (G4); In 2B LDL-KO and ovariectomy group (G5) and in 2C LDL-KO trained ovariectomized group (G6). Asterisk indicates atherosclerosis. H\&E staining. Scale Bar $=100 \mu \mathrm{m}$.

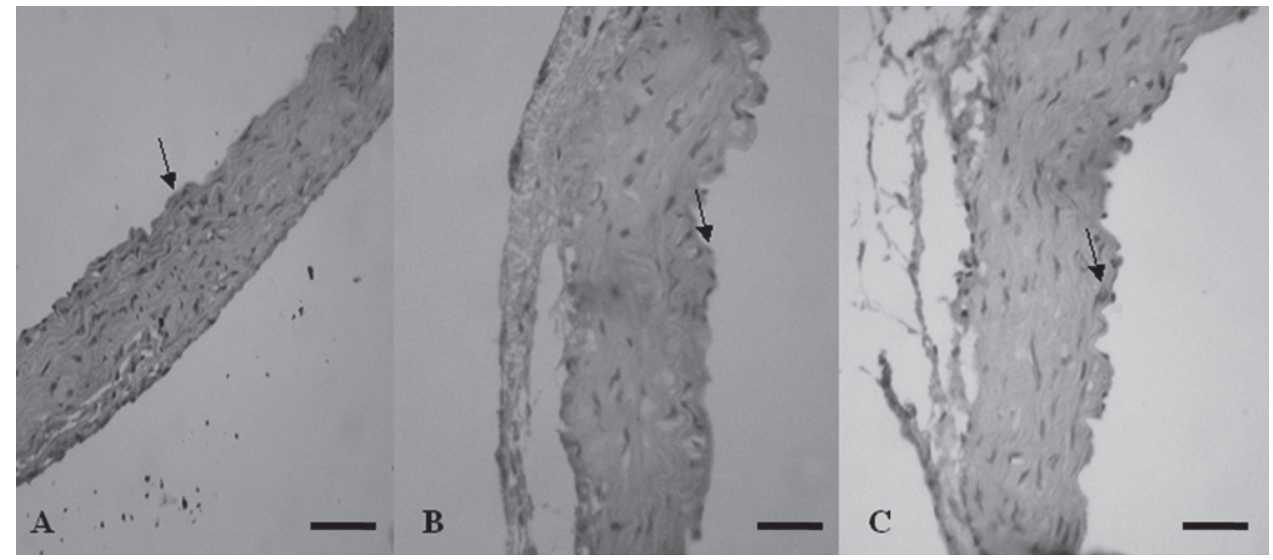

Figure 3 - Immunoexpression of COX-2 (arrow) in G1, G2 and G3 groups. In 3A, sedentary control (G1); In 3B , sedentary control and ovariectomized group (G2) and in $\mathbf{3 C}$ trained control ovariectomized group (G3). Immunohistochemistry staining. Scale Bar $=100 \mu \mathrm{m}$. 


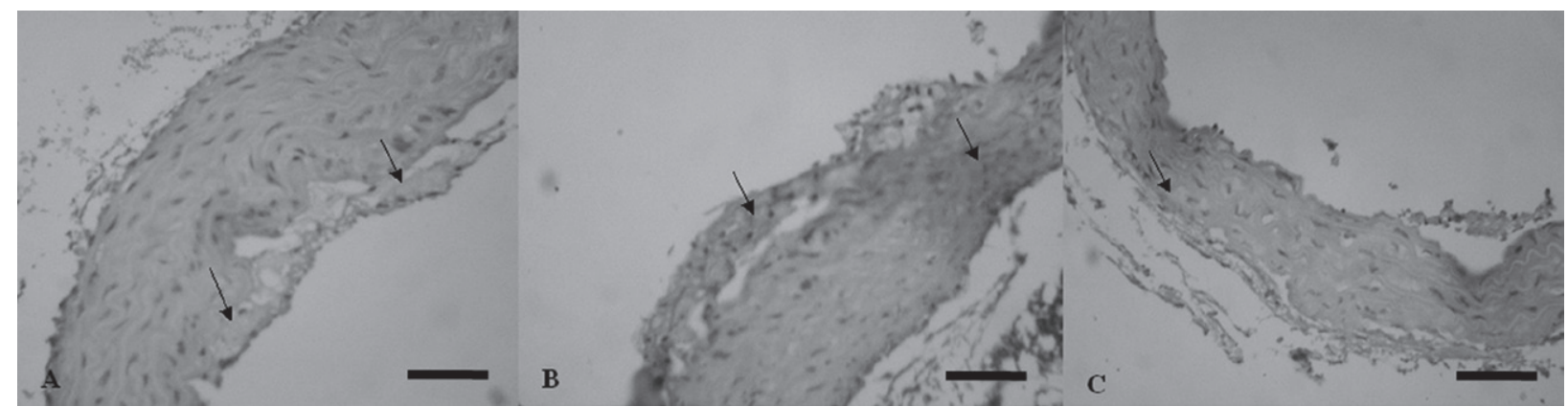

Figure 4 - Immunoexpression of COX-2 (arrow) in G4, G5 and G6 groups. In 4A, LDL-KO sedentary group (G4); In 4B LDL$\mathrm{KO}$ and ovariectomy group (G5) and in 4C LDL-KO trained ovariectomized group (G6). Immunohistochemistry staining. Scale Bar $=100 \mu \mathrm{m}$.

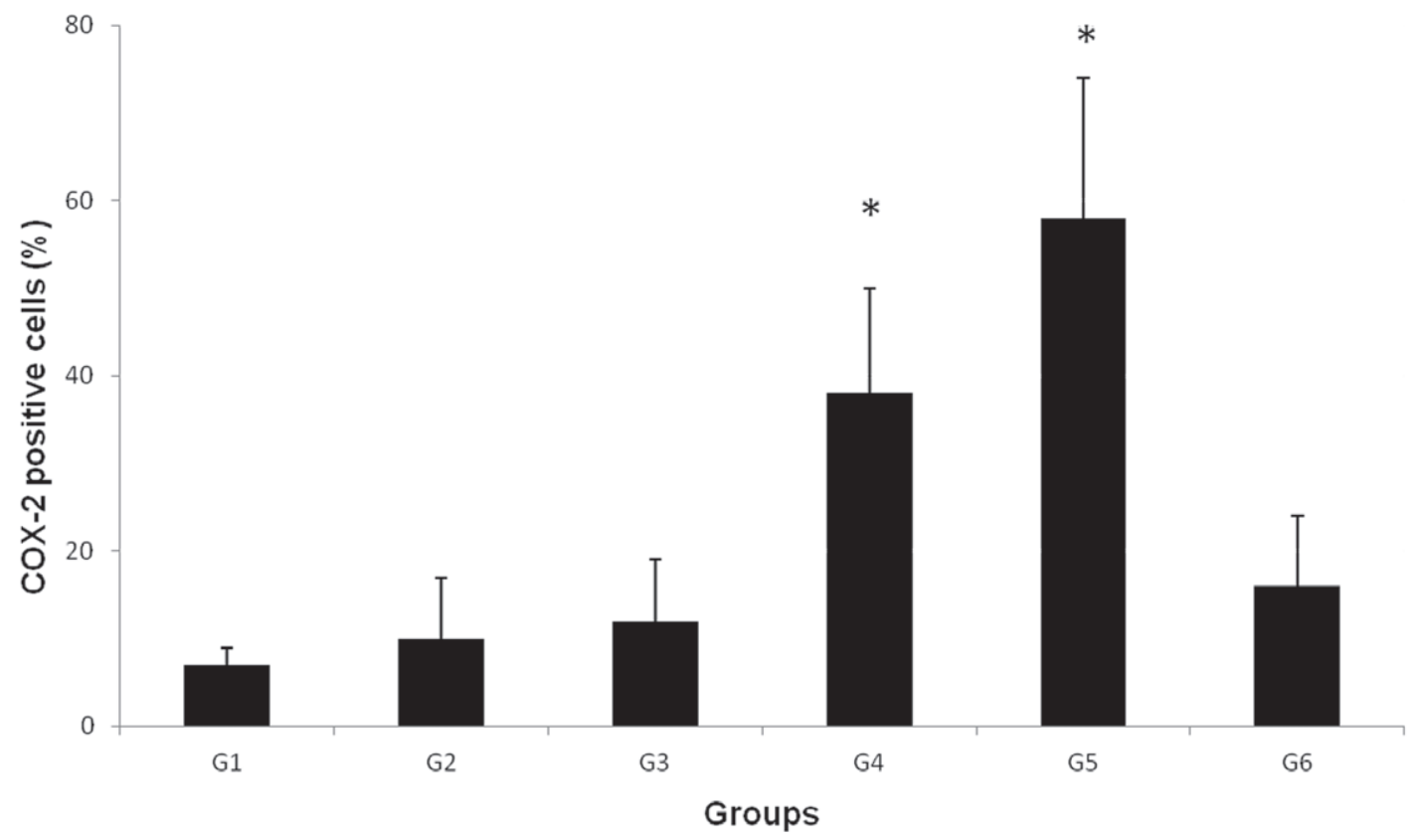

Figure 5 - Graph showing COX-2 labeling index in the groups sedentary control (G1); sedentary control ovariectomized (G2); trained control ovariectomized (G3); LDL-KO sedentary (G4); LDL-KO ovariectomy (G5) and LDL-KO trained ovariectomized (G6).

Values were expressed as means $\pm \mathrm{SD}$. $\left.{ }^{*}\right) \mathrm{p}<0.05$.

\section{DISCUSSION}

The aim of this study was to evaluate the protective effects of exercise training on inflammatory process induced by atherosclerosis in ovariectomized mice. The investigation was conducted using the immunohistochemistry for COX-2. To the best of our knowledge, the approach has not been addressed before.
Histopathological analysis revealed that the groups exposed to exercise training or ovariectomy did not exhibit any morphological changes in this setting. However, LDL-KO mice revealed histopathological changes such as plaque containing cholesterol clefts, foamy histiocytes, and mild inflammatory process. The association of ovariectomy or exercise training did not change the microscopic findings. Taken 
as whole, the outcomes exerted by menopause or exercise training are not able to induce histopathological changes in aortic tissue.

Accumulating evidence suggests that prostaglandin may also play key roles in growth and differentiation control of the several tissues (Cansell et al. 2007). In prostaglandin biosynthesis, cyclooxygenases catalyze the key reactions (Feng et al. 1993). As an important member of the cyclooxygenase isoenzymes, COX-2 was usually found to be expressed in a variety of tumors and inflammatory reactions. To further elucidate the role of COX-2 in dislipidemic mice suffering atherosclerosis, we evaluated the expression pattern of COX-2 in the aortic cells to explore the possible outcomes of certain therapeutic modalities in the normal structure and function of the aorta. Our results demonstrated that $\mathrm{COX}-2$ immunoexpression was weakly detected in mice from the control group (sedentary) as well as in those subjected to ovariectomy or exercise training. However, a strong expression was detected in the atherosclerosis lesion of LDL-KO mice exposed to experimental menopause. In fact, some authors have postulated that COX-2 promotes early atherosclerotic lesion formation in LDL Receptor-Deficient Mice in vivo (Burleigh et al. 2002). By comparison, some studies have provided evidence that selective inhibition of the COX-2 enzyme with celecoxib prevented the development of atherosclerotic lesions in the proximal aortas from apo E-/- mice (Jacob et al. 2008). One of the possible mechanisms is reduction in endothelial expression of the cell intercellular adhesion molecule and vascular cell adhesion molecule, which plays a key role in the recruitment of inflammatory cells during the early stages of atherogenesis. Moreover, some authors demonstrated that selective inhibition of $\mathrm{COX}-2$ and elimination of COX-2 from macrophages significantly reduces early atherosclerotic lesion formation in apoE-deficient and C57BL/6 mice (Burleigh et al. 2005). Deletion of the prostacyclin receptor removed the atheroprotective effect of estrogen in ovariectomized female mice (Egan et al. 2004). Therefore, it seems that COX-2 expression plays an important role in a proatherogenic mechanism, and support the potential of anti-inflammatory therapeutic approaches for atherosclerosis.

Nowadays, there is little information regarding whether exercise training above a certain intensity or duration could have beneficial effects. Accumulating evidence suggests that exercise training enhances oxygen consumption, in an intensity dependent fashion, which is associated with augmented generation of immediate oxidative by-products: reactive oxygen species (Davies et al. 1982). Exercise-induced increases in oxygen radical species production stimulates enzymatic and nonenzymatic antioxidant responses, especially in cases of recurrent efforts (Ascensao et al. 2005). Our results demonstrated that the exercise training associated with dislipidemia was able to reduce COX-2 immunoexpression in aortic cells suferring atheroscherosis. The findings are new, and therefore, difficult to discuss. It has been established that selective inhibition of COX-1 (aspirin) or COX-2 (rofecoxib) does not affect systemic prostacyclin synthesis after physical exercise in trained healthy volunteers (Weber et al. 2007). Conversely, chronic exercise ameliorates the neuroinflammation in mice (Leem et al. 2011). Some authors have assumed that inhibition of COX-2 in cardiomyocytes may contribute to heart failure in patients receiving nonsteroidal anti-inflammatory drugs specific for inhibition of COX-2 (Wang et al. 2009). This requires further study.

Taken together, our results are consistent with the notion that exercise training is able to modulate COX-2 expression in LDL-KO mice as a result of COX-2 down-regulation. As extrapolation from animal to human research requires considerable caution, further studies are warranted to provide additional evidence of the long-term consequences of menopause or exercise training. 


\section{RESUMO}

A diminuição de estrogênio em mulheres pós-menopausa aumenta o risco de doenças cardiovasculares. Esse risco, como resultado da aterosclerose, pode induzir o processo inflamatório e a expressão da Ciclooxigenase-2 (COX-2). O objetivo deste estudo foi investigar a expressão da COX-2 em camundongos fêmeas knockout para o receptor de lipoproteína de baixa densidade (LDL-KO) submetidas ao exercício com ou sem ovariectomia. Um total de 15 fêmeas C57BL/6 e 15 fêmeas LDL-KO foram divididas em 6 grupos: controle sedentário, controle ovariectomizado sedentário, controle ovariectomizado treinado, LDL-KO sedentário, LDL-KO ovariectomizado sedentário e LDL-KO ovariectomizado treinado. A parte ascendente da aorta foi analisada com H\&E e com imunohistoquímica para COX-2. Os resultados revelaram que a ovariectomia bem como o exercício não induziram alterações histopatológicas da aorta dos camundongos em todos os grupos investigados. Camundongos LDLKO demonstraram placas de ateroma, histiócitos espumosos e processo inflamatório moderado em todos os grupos indistintamente. A ovariectomia induziu a forte imunoexpressão da COX-2 na lesão aterosclerótica dos camundongos LDL-KO. No entanto, foi detectada uma diminuição da expressão da COX-2 no LDL-KO ovariectomizado treinado quando comparado com o LDL-KO sedentário. Nossos dados estão de acordo com a noção de que o exercício pode modular a expressão da COX-2 nos camundongos LDL-KO como resultado da diminuição da expressão da COX-2.

Palavras-chave: aterosclerose, Ciclooxigenase-2, exercício, menopausa.

\section{REFERENCES}

Ascensao A, Magalhaes J, SoAREs J, Ferreira R, NeUparth M, Marques F, Oliveira J AND DuARTE J. 2005. Endurance training attenuate doxorubicin-induced cardiac oxidative damage in mice. Int J Cardiol 100: 451-460.

AsiKainen TM, KUKKONEN-HARJUla K AND MillinPalo S. 2004. Exercise for health for early postmenopausal women: a systematic review of randomised controlled trials. Sports Med 34: 753-778.
Baker CS, Hall RJ, Evans TJ, Pomerance A, Maclouf J, Creminon C, Yacoub MH AND POlaK JM. 1999. Cyclooxigenase-2 is widely expressed in atherosclerotic lesions affecting native and transplanted human coronary arteries and colocalizes with inductible nitric oxide synthase and nitrotyrosine particularly in macrophages. Arterioscler Thromb Vasc Biol 19: 646-655.

Burleigh ME, BABAEV VR, OATES JA, HARRIS RC, GAUTAM S, Riendeau D, Marnett LJ, Morrow JD, Fazio S AND LinTON MF. 2002. Ciclooxygenase-2 Promotes early Atherosclerotic Lesion Formation in LDL ReceptorDeficient Mice. Circulation 105: 1816-1823.

Burleigh ME, BABAEV VR, YANCEY PG, MAJOR AS, MCCALEB JL, OATES JA, MORRow JD, FAZIO S AND LINTON MF. 2005. Cyclooxygenase-2 promotes early atherosclerotic lesion formation in ApoE-deficient and C57BL/6 mice. J Mol Cell Cardiol 39: 443-452.

CAnsell MS, Moussaoui N AND Mancini M. 2007. Prostaglandin E2 and interleukin-8 production in human epidermal keratinocytes exposed to marine lipid-based liposomes. Int J Pharm 343: 277-280.

DAVIES KJ, QUINTANILHA AT, BROOKS GA AND PACKER L. 1982. Free radicals and tissue damage produced by exercise. Biochem Biophy Res Commun 107: 1198-1205.

EgAN KM, LAWSON JA, Fries S, Koller B, RADER DJ, SMYTH EM AND FITZGERALD GA. 2004. COX-2-derived prostacyclin confers atheroprotection on female mice. Science 306: 1954-1957.

Feng L, Sun W, Xia Y, TANG WW, Chanmugam P, SOYOOLA E, WILSON CB AND HwANG D. 1993. Cloning two isoforms of rat cyclooxygenase: differential regulation of their expression. Arch Biochem Biophys 307: 361-368.

Hong J, STUBbins RE, SMith RR, HARVEY AE AND NunEZ NP. 2009. Differential susceptibility to obesity between male, female and ovariectomized female mice. Nutr J 18: 8-11.

IRIGOYEN MC, PAULINI J, FloREs LJF, Flues K, BERTAGNOLli M, Moreira ED, CONSOlim-Colombo F, Bello-Klein A AND DE ANGELIS K. 2005. Exercise Training Improves Baroreflex Sensitivity Associated With Oxidative Stress Reduction in Ovariectomized Rats. J Hypertension 46: 998-1003.

JACOB S, LAURY-KLEINTOP L AND LANZA-JACOBY S. 2008. The select cyclooxygenase- 2 inhibitor celecoxib reduced the extent of atherosclerosis in apo E-/- mice. J Surg Res 146: 135-142.

LeEM YH, LEE YI, SON HJ AND LEE SH. 2011. Chronic exercise ameliorates the neuroinflammation in mice carrying NSE/htau23. Biochem Biophys Res Commun 18: 359-365.

LUdGERO-CORREIA A JR, Aguila MB, MANDARIM-DELACERDA CA AND FARIA TS. 2011. Effects of high-fat diet on plasma lipids, adiposity, and inflammatory markers in ovariectomized C57BL/6 mice. Nutrition 28: 316-323.

MARSh MM, WALKER VR, CURTISS LK AND BANKA CL. 1999. Protection against atherosclerosis by estrogen independent of plasma cholesterol levels in LDL receptordeficient mice. J Lipid Res 40: 893-900. 
PETERSEN AM AND PEDERSEN BK. 2005. The anti-inflammatory effect of exercise. J Appl Physiol 98: 1154-1162.

Rodrigues B, Figueiroa DM, Mostarda CT, HeEren MV, IRIGOYEN MCAND DE ANGELIS K. 2007. Maximal exercise test is a useful method for physical capacity and oxygen consumption determination in streptozotocin-diabetic rats. Cardiovasc Diabetol 13: 6-38.

Ross R. 1999. Atherosclerosis: an inflammatory disease. N Engl J Med 340: 15-126.

SCHONBECK U, SukHOVA GK, GRABER P, COUTER S AND LIBBY P. 1999. Augmented expression of cyclooxygenase-2 in human atherosclerotic lesions. Am J Pathol 155: 1281-1291.

Souza SBC, Flues K, Paulini J, Mostarda C, Rodrigues B, SOUZA LE, IRIGOWEN MC AND DE ANGELIS K. 2007. Role of Exercise Training in Cardiovascular Autonomic Dysfunction and Mortality in Diabetic Ovariectomized Rats. Hypertension 50: 786-79.
Vieira RP, Claudino RC, Duarte AC, Santos AB, Perini A Faria Neto HC, MaUAD T, Martins MA, DolhniKofF M AND CARVALHO CR. 2007. Aerobic exercise decreases chronic allergic lung inflammation and airway remodeling in mice. Am J Respir Crit Care Med 176: 871-877.

WANG D ET AL. 2009. Cardiomyocyte cyclooxygenase-2 influences cardiac rhythm and function. Proc Natl Acad Sci 106: 7548-7552.

Weber AA, Heim HK, Schumacher M, Schror K AND HOHLFELD T. 2007. Effects of selective cyclooxygenase isoform inhibition on systemic prostacyclin synthesis and on platelet function at rest and after exercise in healthy volunteers. Platelets 18: 379-385. 